\title{
FLICKER EXPLOITS HORNET AND WASP NESTS IN WINTER
}

FRANK H. BRAZIER, 2657 Cameron St., Regina, Saskatchewan. S4T 2W5

In the autumn of 1982 about $3 \mathrm{~m}$ up in the old rowan tree in our front yard I noticed a nest of the insect popularly known as the Bald-faced Hornet. I had occasionally seen them drinking at the birdbath underneath that tree. Somewhat earlier I had discovered the nest of the yellowjacket or wasp concealed in the dense foliage of an old honeysuckle bush at the southwest corner of our home. As we faced west we had a good view through out picture window of most of the front yard.

December 2, 1982, was a cool day, windy, with some snow. I was home about 11:00 a.m. looking out of the window when I noticed debris from the hornet nest drifting past to the south. I went out and saw a male Northern Flicker working on the nest. $\mathrm{He}$ had worked on it until the cells were exposed. Then he positioned himself just below it on a convenient branch and systematically plundered the cells. I saw an occasional hornet in his bill before it was swallowed. Finally he flew off to a nearby ash tree and clung to the trunk on the lee side, out of the wind. He rested there for about 20 minutes but when I looked later he had gone. The wasp nest had been damaged but was still largely intact.

I did not see the Flicker again until December 23 but he must have been back at intervals because the hornet nest had been completely destroyed. On that day, he returned in the afternoon and attacked the wasp nest but was soon disturbed and flew off. He was back again about 12:30 p.m. on December 28, attacking the wasp nest; he left after making considerable inroads on the structure. He was back the next day at 11:00 a.m. and again at 3:00 p.m. when he finished it off. He visited the wasp nest remains briefly on January 2,1983 . I thought he was gone for good and, so, was surprised to see him again at 1:00 p.m. on February 7,1983 , working over the nest remains, both on the ground and in the bush, for nearly an hour. I never saw him again.

About two years ago I had occasion to consult Keith Roney, entomologist of the Saskatchewan Museum of Natural History, about wasps. He told me that our wasps and hornets, which are closely related, do not stop reproducing in the fall but continue until cold weather kills every insect in the nest. The mated queens hibernate elsewhere, in holes in the ground or under leaf litter, until spring when the cycle begins anew.

I was told that five species of wasps and two species of hornets occur here, so, without actual 
specimens it was not possible to give their scientific names. To the average person "yellowjacket" and "wasp" are the same; "Bald-faced Hornet" (or sometimes "White-faced Hornet") is the official common name of both hornets that are here and when close enough to see details the hornet is obviously not a yellowjacket.

Both hornets and wasps start their nests at the top, constructing new layers as they go down, so the insects at the top are the farthest advanced and the lower tiers contain pupae and eggs of different ages.
The nests of both the hornet and the wasp that I had in my front yard were similar, each about $15 \mathrm{~cm}$ diameter at the widest near the top, and roughly oval in shape.

As an appropriate footnote I would add that in the winters of 1957, 1958 and 1959, Elmer Fox, his son Reg and I walked from Bredin Siding along the valley of Boggy Creek to Lumsden, as part of the Christmas Bird Count, and on occasion we saw magpies plundering the wasp or hornet nests that had been constructed in low bushes.

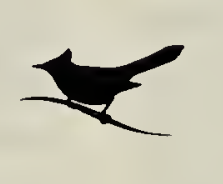

\section{NOTICE}

\section{WANTED: BIRD RECORDS FOR YUKON TERRITORY}

The Canadian Wildlife Service is compiling a database of current and historical bird records for Yukon Territory. The database will be used to produce a publication called Birds of the Yukon, which will include species accounts and grid-style distribution maps for all Yukon species.

If you have visited the Yukon and kept bird notes, please send a copy of your notes to Pam Sinclair, Canadian Wildlife Service, Box 6010, Whitehorse, Yukon, Y1A 5L7. Fairly exact locations of sightings are essential for mapping, which will be based on 1:50,000 scale NTS map sheets. In addition, any evidence of breeding (nests found, adults feeding young, young-of-the-year observed, etc.) would be very useful. All contributions will be acknowledged in the publication. 